\title{
実天候条件を用いた太陽光発電システムの 新しいシミュレーション方法及びその忘用例
}

\author{
学生員 朴 敏 遠 終身会員 松 浦 虔 士 (大阪大学) \\ 学生員山下博 史 正員 道 平 雅一 (神戸高尃)
}

\author{
A Novel Simulation Method for PV Power Generation System \\ using Real Field Weather Condition and its Application
}

\author{
Minwon Park, Student Member, Kenji Matsuura, Life Member (Osaka University) \\ Hiroshi Yamashita, Student Member, Masakazu Michihira, Member (Kobe City College of Technology)
}

\begin{abstract}
In order to verify the efficiency or availability and stability of photovoltaic generation systems, huge system apparatuses are needed, in general, in which an actual size of solar panel, a type of converter system and some amount of load facilities should be installed in a particular location. It is also hardly possible to compare a MPPT control scheme with others under the same weather and load conditions in an actual PV generation system. The only and a possible way to bring above-mentioned problem to be solved is to realize a transient simulation scheme for PV generation systems using real weather conditions such as insolation and surface temperature of solar cell. The authors, in this paper, introduce a novel simulation method, which is based on EMTP and EMTDC, for PV generation systems under the real weather conditions. Firstly, VI characteristic equation of a solar cell is simulated and implemented, and then the real data of weather conditions are interfaced to EMTP and EMTDC program using Fortran program interface method. The outcome of the simulation demonstrates the effectiveness of the proposed simulation scheme. The result shows that the cost effective verifying for the efficiency or availability and stability of PV generation systems and the comparison research of various control schemes like MPPT under the same weather conditions are possible.
\end{abstract}

Key words: Photovoltaic generation system, EMTP, ATP, EMTDC, VI characteristic equation, Simulation

\section{1.まえがき}

近年、太陽光発電、風力発電、燃料電池の 3 つが、環境 負荷の少ない新しいエネルギー源としてもっとも熱い脚光 を浴びている。太陽光発電の場合、導入支援、規制の合理 化、技術開発そして標準化など、国としても「新エネルギ 一大網」を策定し、太陽光発電システムの導入促進を推し 進めてきた結果、日本で一番普及が進んでいる新エネルギ 一源となっている。太陽光発電は、クリーンで無公害であ り、放棄エネルギーが有効利用できるなど様々な長所があ る。しかしながら、太陽光発電の発電電力量は、天候条件 に強く依存するという本質的な問題がある。これを解決し、 効率良く電力を得るためには最大電力追従制御が不可欠と なり、また、交流負荷への連系を考える場合、太陽光発電 から得られた直流電力を交流電力八変換するインバータが 必要となる。このように制御装置や電力変換装置、太陽電 池モジュールを必要とする太陽光発電システムは、実用化 はもちろんのこと研究段階においても実験的に検証を行お うとすればかなりの費用がかかることになる。特に研究段 階では、太陽電池の種類や規模、インバータの構成、最大 電力追従制御方式など様々な組み合わせが考えられ、それ ぞれについてシステムを製作し、安定性や効率などの評価
をしなければならない。また、制御方式など新たな提案を 行った場合、その有効性を明らかにするには従来方式との 比較検傠が必要となるが、同じ天候条件で比較検討を行お うとすれば、同一規格の装置を最低でも 2 台以上準備しな ければ同時に実験を行い評価することは不可能である。こ のように、信賴性の高い実験、評価を行うにはかなりの設 備投資が要求され、決して経済的であるとはいえない。

そこで、実験に代わる評価方法としてシミュレーション 解析がある。シミュレーション手法は主にその使用する目 的によって、定常状態シミュレーションと過渡現象シミュ レーションに別けられる。定常状態シミュレーションは、 実際の天候データを瞬時值として取り扱うのではなく、整 くても 10 分程度の期間でこれらを積算し、その積算值を環 境データとして用いるもので太陽光発電システムの提案や 経済的評価(1)、デザインや規模の評洒(2-3)などを目的として いる。この手法は、広く普及しており多くの研究報告もな されている。しかしながら、この手法では積算期間内に寒 際に天候が急変したとしても考慮されないため、MPPT 制 御の提案や追従性、制御性などの評価はできない。これら を評価するに法、天候条件を秒単位で取り扱う過渡状態シ ミュレーションが不可欠なる。太陽光発電システムにおい て、MPPT 制御を含む制御方式の検討は、システムの高効 
率化や性能を評価する上で重要であるにも関わらず、現在 のところ過渡状態シミュレーションに関する報告はほとん どないと言っても過言ではない。そこで、著者らは太陽光 発電システムの制御性や系統への影響等の評価を可能にす るため、太陽電池の詳細なモデル化を提案し、天候条件の 瞬時値を用いる新しい過渡状態シミュレーション法を提案 した (4-5)。(以後、本稿で記述する実天候条件とは環境データ の瞬時值を示す)この特徵は、太陽電池を特性方程式を用 いて詳細にモデル化することにより、太陽光発電容量や太 陽電池の種類（単結晶や多結晶など）を自由に設定できる ようにしたところである。また、過渡的に変化する実際の 天候条件をデータとして読み込み、そのデータからシミュ レーションを行うことで、最も現実に近い太陽光発電シス テムの過渡現象解析を実現させた。さらに、シミュレーシ ヨンツールとしては、電カシステムの過渡現象解析プログ ラムとしてもっとも信頼性が高いとされている EMTP 型シ ミュレータ(6)である EMTP/ATP(7)、EMTDC(8)を用いている。 これらのツールを使用したのは、過渡現象解析プログラム として一般性が強いこと、太陽光発電システムの系統への 影響など発電から柔統までのトータルな解析が行えること が大きな理由である。本論文では、提案するシミュレーシ ヨン方法を示し、得られた解析結果と実験結果との比較検 討を行いその妥当性について述べる。また、最大電力追従 制御方式や電力変換装置の構成を変化させ、得られた結果 を示すとともに、提案シミュレーション方法の汎用性と有 効性について述べる。

\section{2. 太陽電池の電圧電流特性方程式のモデル化}

$<$ 2.1>電压電流特性方程式単一太陽電池セルの電圧電 流特性方程式を正確に定義するのは難しく、最も一般化さ

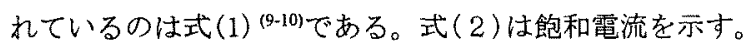

$$
\begin{aligned}
& I=I_{s c}-I_{o s}\left\{\exp \left[\frac{q \cdot\left(V+I \cdot R_{s}\right)}{n \cdot k \cdot T}\right]-1\right\}-\frac{V+I \cdot R_{s}}{R_{s h}} \\
& I_{o s}=A T^{\gamma} \exp \left(\frac{-E_{g}}{n \cdot k \cdot T}\right) \\
& I_{s c}=B \cdot s
\end{aligned}
$$

ここで、 $I=$ 太陽電池セルの出力電流 $[\mathrm{A}] 、 I_{s c}=$ 短絡電流 $[\mathrm{A}]$ $I_{o s}=$ 飽和電流 $[\mathrm{A}] 、 s=$ 日射強度 $\left[\mathrm{kW} / \mathrm{m}^{2}\right] 、 q=$ 電子の電荷量 ; $1.6 \mathrm{e}-19[\mathrm{C}] 、 k=$ ポルツマン定数 $; 1.38 \mathrm{e}-23[\mathrm{~J} / \mathrm{K}] 、 T=$ 太陽電 池 $\mathrm{PN}$ 接合部分温度 $\left[{ }^{\circ} \mathrm{K}\right] 、 n=$ 接合定数、 $A=$ 飽和電流温度 係数、 $B=$ 日射強度 $1.0 \mathrm{~kW} / \mathrm{m}^{2}$ での短絡電流レベル、 $\gamma=$ 温 度依存度、 $E_{\mathrm{g}}=$ エネルギーギャップ $[\mathrm{eV}] 、 V=$ 太陽電池セ ルの出力電圧 $[$ Volt $] 、 R_{s}=$ 直列蒿生抵抗 $[\Omega] 、 R_{s h}=$ 並列寄生 抵抗 $[\Omega]$ である。

表 1 本稿で用いた太陽電池セルの特性パラメータ Table 1 Characteristic parameters of the solar cell used

\begin{tabular}{c|c||c|c|c|c|c|c}
\hline $\mathrm{n}$ & 1.5 & $\gamma$ & 3 & $\mathrm{~A}$ & $9.0 \mathrm{e}-2$ & $\mathrm{E}_{\mathrm{g}}$ & $1.103 \mathrm{eV}$ \\
\hline \multicolumn{2}{c|}{$\mathrm{R}_{\mathrm{s}}$} & $0.028 \Omega$ & \multicolumn{2}{c|}{$\mathrm{R}_{\mathrm{sh}}$} & $1 \mathrm{k} \Omega$ \\
\hline $\mathrm{V}_{\mathrm{cc}}$ at $25^{\circ} \mathrm{C}$ & 0.58 Volt & \multicolumn{2}{|c|}{$\mathrm{B}$} & 3.0 \\
\hline
\end{tabular}

表 1 は、本稿で用いた多結晶シリコン太陽電池セルの特 性パラメータである。これらの特性パラメータは、実際に 使用寸る太陽電池セルの数値に書き変えるだけで様々な太 陽電池セルを模擬することができる。

<2.2>EMTP/ATP および EMTDC を用いた太陽電池電圧 電流方程式のモデル化電力システムのシミュレーショ ンツールには、電源として電圧源と電流源が備わっている。 しかしながら、太陽光発電システムのシミュレーションを 考えた場合、電源となる太陽電池は、電圧源とも電流源と も言えない電圧電流特性となるため、新たなモデル化が必 要となる。そこで、図 1 に示すような太陽電池の電仕電流 特性方程式を用いた新しい太陽電池のモデルを提案する。

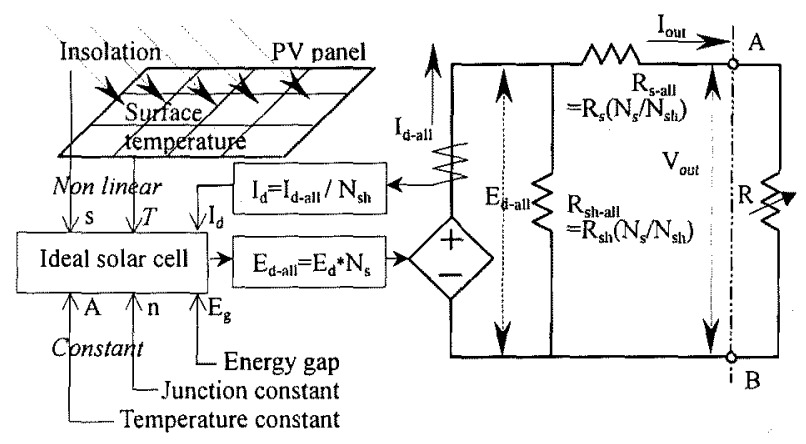

図 1 太陽電池モジュールのシミュレーション概念図

Fig. 1 Image diagram of simulation for a solar module

図 1 から、 $E_{d}=$ 太陽電池セルの理想出力電圧[Volt]、 $E_{d-a l l}$ $=太$ 陽電池モジュールの理想出力電圧 $[$ Volt $] 、 I_{d}=$ 太陽電池 セルの理想出力電流 $[\mathrm{A}] 、 I_{d-a l l}=太$ 太陽電池モジュールの理想 出力電流 $[\mathrm{A}] 、 V_{o u t}=$ 太陽電池モジュールの出力電圧[Volt $] 、 I_{o u t}$ $=太$ 陽電池モジュールの出力電流 $[\mathrm{A}] 、 N_{s h}=$ セルの並列数、

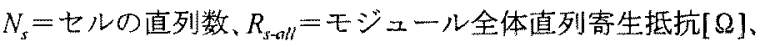
$R_{\text {sh-all }}=$ モジュール全体並列奇生抵抗 $[\Omega] 、 R=$ 外部負荷であ る。図 1 の奇生抵抗分を除いた単一太陽電池セルの理想 P. $\mathrm{N}$ 接合太陽電池の VI 特性非線型方程式は式 (4)で示す。

$$
I_{d}=I_{s c}-I_{o s}\left\{\exp \left[\frac{q}{n \cdot k \cdot T} \cdot E_{d}\right]-1\right\}
$$

本論文では、パラメータである日射強度、太陽電池表面 温度及び $I_{d \cdot a l}$ から得られた $I_{d}$ を式(4)に代入し、 $E_{d}$ を計算 する。その $E_{a^{\prime}}$ から $E_{d \cdot a l l}$ を計算し、それを EMTP/ATP や EMTDC $の$ GUI (Graphic User Interface)上で、電圧源として 用いる。一計算刻み嵲に電流 $\left(I_{d}\right)$ を含むパラメータを電圧 $\left(E_{d}\right)$ に反映させるため、正確には一計算刻み分、電圧の忘 答注遅れるが、暑れは回路応答に比べ非常に短いため、影 響は無視できる。すなわら、図 1 の-B 端子間電圧と電流 が、太陽電池モジュールの出力となる。

$<2.3>$ 奏天候条件の使用 EMTP/ATP EMTDCなどの 電力システム用の過渡現象デジタルシミュレーションツー ルを用いた太陽光発電システムのシミュレーションでは実 際の天候条件を模擬することは不可能である。そのため天 候条件などの外部パラメータが必要なシミュレーションで 
は信頼性が低いと言える。そこで、提案シミュレーション 方法ではフォートラン言語とのインターフェース方法を導 入し、ノンリニアな外部パラメータすなわち実天侯条件を EMTP/ATP 及び EMTDC に読み込ませることにした。この 結果、実データの天候条件を用いた太陽光発電システムの シミュレーション解析がはじめて実現されることになった。

図 2 は EMTDC を用いる提案した非線形な外部バラメー 夕索慮したシミュレーション方法のフローチャートであ る。実際に測定した日射強度、表面温度のデータは、フォ 一トラン言語とのインターフェース方法を用いて、シミュ レーション内部に読み込ませる。よって、日射強度などの 実データを用いたシミニレーション解析が可能となる。 EMTP/ATP の場合も同じ概念図であるが、EMTDC とは異な る OSを使用するためPCだけですべて動作が可能となる。

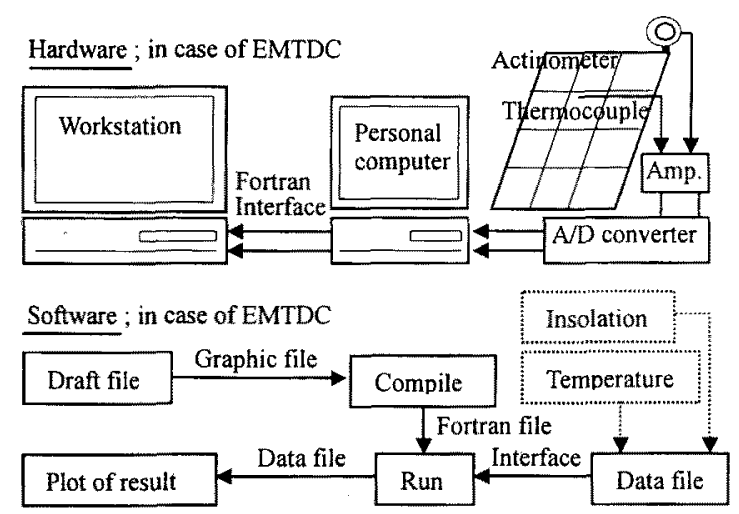

図 2 EMTDCで実天候条件を用いるための概念図

Fig. 2 Simulation diagram on EMTDC using real weather condition

<2.4>日射強度デー夕の再構成 既に知られているよう に測定された日射強度のデータは式(5)のように使用する日 射計の種類によって異なるが特性応答性によって歪みを受 ける。

$$
R I(s) \frac{G}{1+s T}=M I(s)
$$

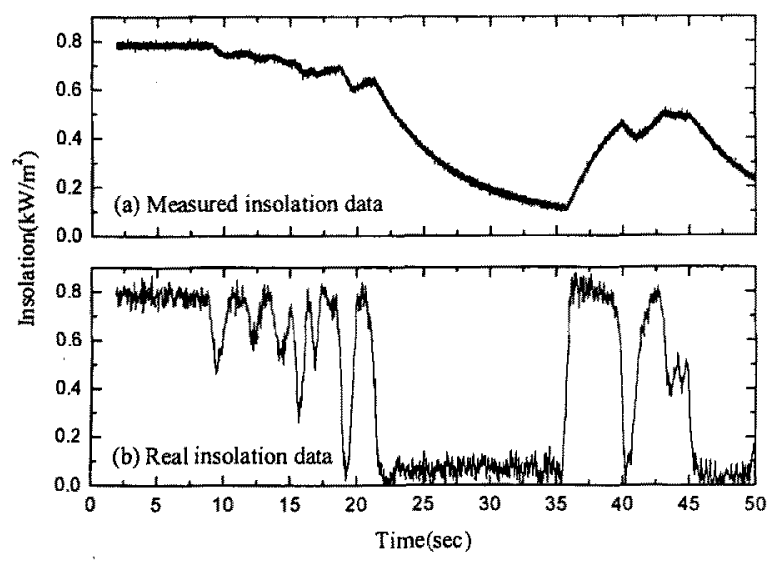

图3日射強度データの再構成

Fig. 3 Reformation of the insolation data
ただし、RI(s)=実際の日射強度、MI (s)=測定された日射強 度、 $G=$ 日射計のゲイン定数、 $T=$ 時定数である。本研究で用 いた日射計(11)の応答速度が 17 秒であるため、パラメータは $G=1.0, T=5.67$ である。

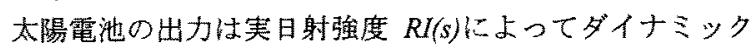

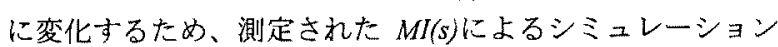
解析は本来の過渡解析とは異なる。シミュレーションでは

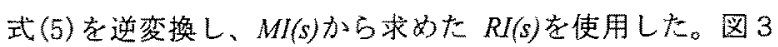
に日射計から測定されたデータと再構成した害日射強度デ 一タを示す。このように再構成することにより日射強度の ダイナミックな変化を捉えることができる。本研究のシミ ュレーションで使用した日射強度データは、全て式(5)によ り再構成したものである。

\section{3. 太陽電池に関する解析結果}

<3.1>用いた太陽電池アレイと测定装置実際のデータ を測定するために設置した太陽電池アレイの仕様を表 2 に 示す。ただし、セル単体の特性は表 1 に示すものである。 また測定を行うための測定装置の概略在図 4 に示す。本研 究では、これらの装置を用いて実験を行っている。

\section{表 2 設置された太陽電池アレイの規模}

Table 2 Size of the established PV array

\begin{tabular}{l||c|c||c|c}
\hline A panel $=36$ cells in series & $V_{\text {oc-arrav }}$ & 120 Volt & $1_{\text {scarrav }}$ & $6 \mathrm{~A}$ \\
\cline { 2 - 5 } $\begin{array}{l}\text { An array }=\left(\mathrm{N}_{\mathrm{s}}=216, \mathrm{~N}_{\mathrm{sin}}=2\right) \\
6 \text { panels in series } \times 2 \text { in parallel }\end{array}$ & $\begin{array}{c}\text { Fill } \\
\text { Factor }\end{array}$ & $62.9 \%$ & $\begin{array}{c}\text { Rated } \\
\text { Power }\end{array}$ & $445 \mathrm{~W}$ \\
\hline
\end{tabular}

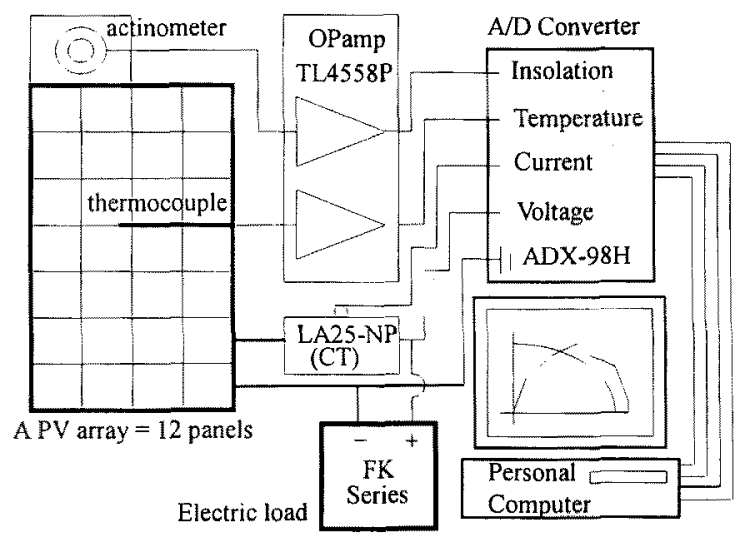

図 4 測定装置の概念図

Fig. 4 Diagram of the measurement apparatus

$<3.2>$ 天侯条件と太陽電池アレイの出力変化提案した 太陽電池のモデル化の妥当性を確認するために、まずは設 置した太隄電池アレイの出力電圧、電流の測定を行った。 測定条件しして、太陽電池アレイの出力端子に電子負荷装 置を接続し、50 秒間鱼荷を変化させたときの出力電圧、電 流をアナログ/デジタルコンバータからパソコンにより測定、 データ化した。電子負荷装置による負荷アドミタンスの変 化は図 5 に示す通りである。 


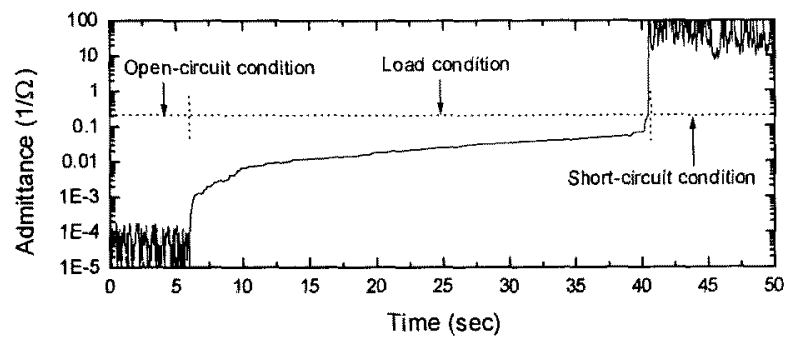

図 5 電子負荷装置による負荷アドミタンスの変化

Fig. 5 Changed admittance of load by electric load

また、このとき日射強度、太陽電池の表面温度も 50 秒間 測定している。その結果は図6に示す。

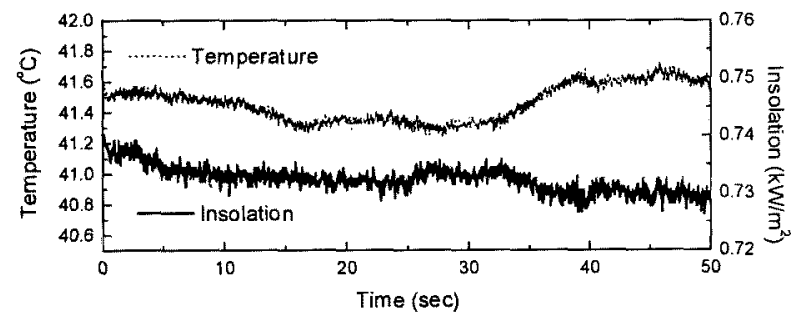

図6太陽電池パネルの表面温度と日射強度

Fig. 6 Module surface temperature of PV panel and insolation
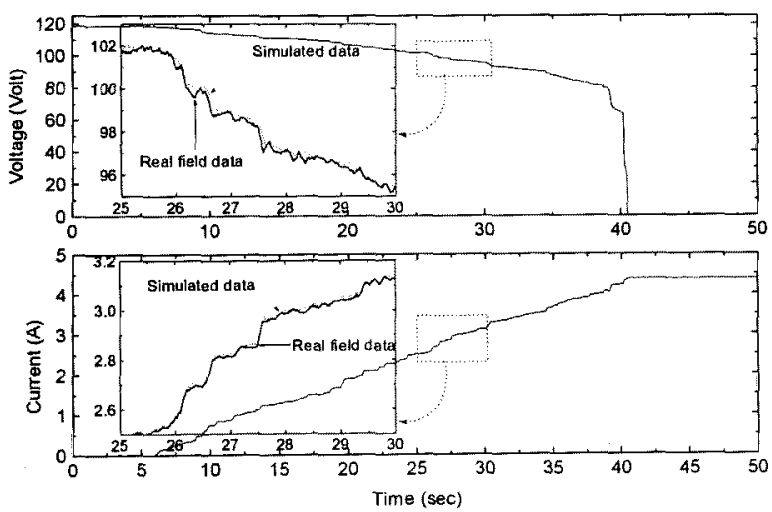

図 7 太陽電池アレイの出力電压、電流の比較

Fig. 7 Voltage and current curves by real apparatus and simulation

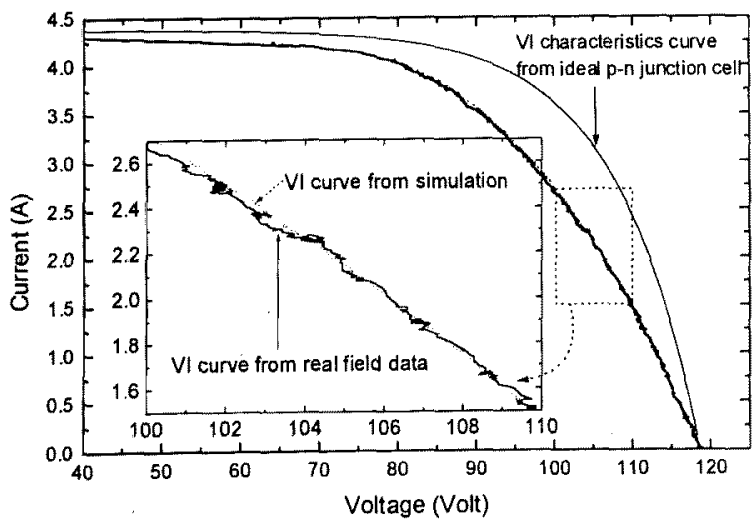

図 8 電质電流特性曲線

Fig. 8 Voltage-current characteristics curves
<3.3>シミュレーション結果との比較検討 図 6 に示す 日射強度、表面温度の測定データを式 (4)に代入、また図 5 に示す負荷アドミタンスの測定データは図 1 の外部負荷 $\mathrm{R}$ のアドミタンスとして入力し、50 秒閒のシミュレーショ ン解析を行った。シミュレーションのサンプリング時間は 40 $\mu \mathrm{s} 、$ データの入力サンプリング周期は $100 \mathrm{~Hz}$ である。図 7 、 8 に測定結果とシミュレーション結果を示す。図 7 㹥、太 陽電池アレイの出力電汗、電流であり、図 8 はそれらの結 果から得られた VI 特性である。これらの図から明らかなよ うに測定結果とシミュレーション結果はよく一致しており、 提案した太陽電池のモデル化と実データを用いたシミュレ ーションオ法から得られる解析結果の妥当性は確認された ものと言える。尚、紙面の都合上、解析結果の一例を示す にとどまっているが、様々な条件下での比較検討も行って 抢り、これらもよく一致した結果が得られている。

4. DC-DC コンバータを用いた太陽光発電システムの 出力特性

<4.1> DC-DC コンバータを用いた太陽光発電システム この章では、電力変換装置により出力制御を行った時の太 陽電池アレイの動作及び出力特性を確諮するため、図 9 に 示す太陽光発電システムを構築し検討を行う。電力変換装 置として DC-DC コンバータを適用し、太陽電池アレイの出 力端子に接続する。制御は、この DC-DC ニンバータで太陽 電池出力電圧一定制御(12) を行うものとする。また、負荷は 単独負荷を想定している。使用した回路定数、制御条件は 表 3 に示寸通りである。次に、実験及びシミュレーション で用いた天候条件は図 10 に示した 50 秒間である。出力䨍 圧一定制御の応答も確認する必要があるため、厚い雲が設 置している太陽電池アレイの上空から去って行き、日射強 度に急激な変動が起こった期閒を選択した。

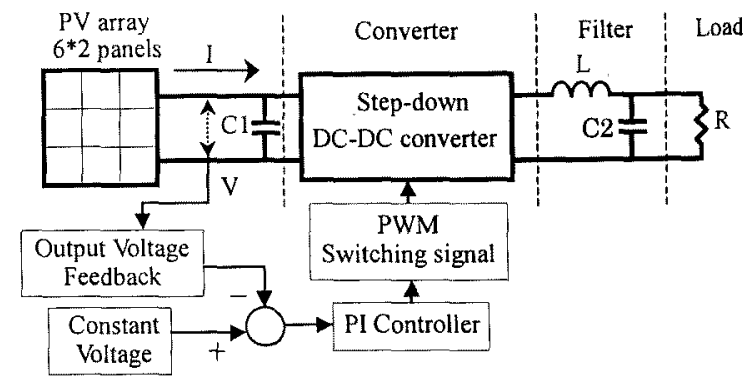

图 9 DC-DC コンバータを用いた太陽光発電システム

Fig. 9 Diagram of the PV power system using DC-DC converter

表 3 回路定数及び制御条件

Table 3 Circuit parameters and control condition

\begin{tabular}{c|c|c|c}
\hline \multicolumn{3}{|c|}{ PWM switching frequency } & $10 \mathrm{kHz}$ \\
\hline Control of the output voltage of $\mathrm{PV}$ array & 80 Volt constant \\
\hline $\mathrm{Cl}$ & $10 \mathrm{mF}$ & $\mathrm{C} 2$ & $5 \mu \mathrm{F}$ \\
\hline $\mathrm{L}$ & $0.8 \mathrm{mH}$ & $\mathrm{R}$ & $45 \Omega$ \\
\hline \multicolumn{2}{|c|}{ Simulation sampling frequency } & $10 \mu \mathrm{s}$ \\
\hline Cycle of the real weather condition input data & $100 \mathrm{~Hz}$ \\
\hline
\end{tabular}




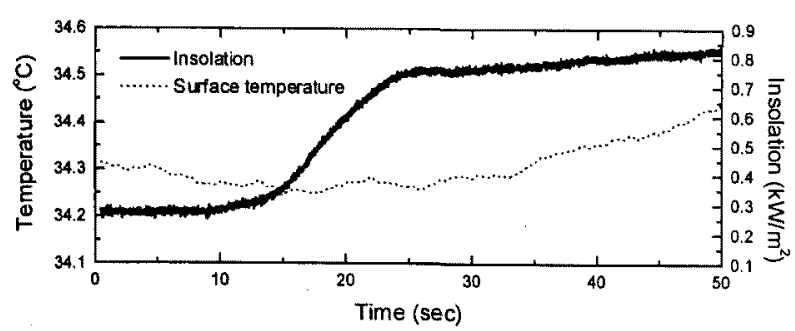

図 10 急激な日射強度変動を伴った実天候条件

Fig. 10 Real weather condition with the fluctuation of insolation

<4.2>実験結果とシミュレーション結果の比較検討 図 9 で示したシステム、図 10 で示した天候条件下で出力 電圧一定制御（出力電圧を 80[Volt]に設定）を行った実験結 果及びシミュレーション結果を図 11 、図 12 に示す。図 11 は、太陽電池アレイの出力電圧波形、図 12 は太陽電 池アレイの出力電流波形である。出力電圧波形からわかる ように、実験結果、シミュレーション結果ともに 80[Volt]に 制御がなされており、DC-DC コンバータが正常に動作して いることが確認できる。また、出力電流波形から、日射強 度の変化とともに出力電流が増加している現象が確認でき、 その現象は実験結果とシミュレーション結果はよく一致し ている。

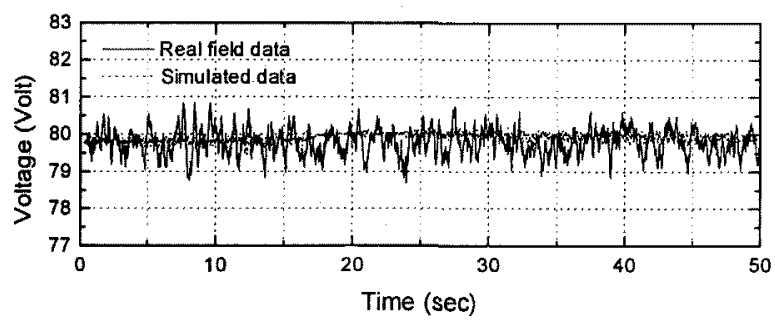

図 11 太陽電池アレイの出力電圧波形

Fig. 11 The output voltage curves of PV array

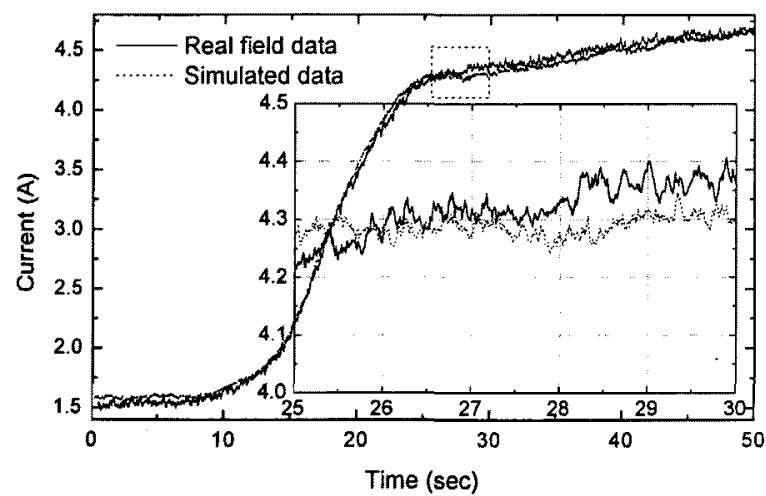

図12 太陽電池アレイの出力電流波形

Fig. 12 The output current curves of PV array

しかし、図12の拡大波形を見ると、微妙に2つの波形 に誤差が生じている。これは、設置した太陽電池アレイの 面積 $\left(6 \mathrm{~m}^{2}\right)$ と日射計センサ一部の面積 $\left(6 \mathrm{~cm}^{2}\right)$ の面積差 による雲陰の消去時閒の差、つまり、実際に太陽電池アレ
イが受けた日射強度とセンサー部で感じた日射強度との時 間差による誤差と考えられるため、本質的な問題ではない といえる。以上の結果より、電力変換装置と出力制御を含 むシステムに対しても提案したシミュレーション方法及び 太陽電池アレイのモデル化により良好な解析結果が得られ ることが確認された。

\section{5. 太陽光発電系統連系システムの特性解析}

<5.1> 系統連系システムとシミュレーション条件ここ の章では、妥当性が確認された提案シミュレーション法を 用いて、太陽光発電系統連系システムについて動作解析を 行う。ここでは、系統連系を行った太陽光発電システムに 対して、最大電力追従制御を行った時の動作解析、異なる 制御方式を用いた時の動作の違いなどについて険討を行う。 図 13 にミュレーション解析に用いた系統連系太陽光発 電システムの概念図を示す。電力変換装置は、交流出力を するために DC-AC コンバータ（系統連系用インバータ）と した。ここで、 $I_{p v}=$ 太陽電池アレイの出力電流、 $V_{p v}=太$ 太陽 電池アレイの出力電圧、 $P_{p v}=$ 太陽電池アレイの出力電力、 $V_{r e f}$ $=\mathrm{MPPT}$ 制御からのレファレンス電圧、 $I_{o}=$ コンバータの出

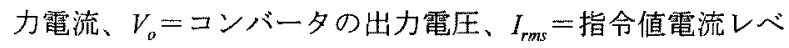
ル、 $I_{r f}=$ 指令值電流、 $\mathrm{sw} 1=$ 分散電源側スイッチ、sw2=系 統側スイッチである。

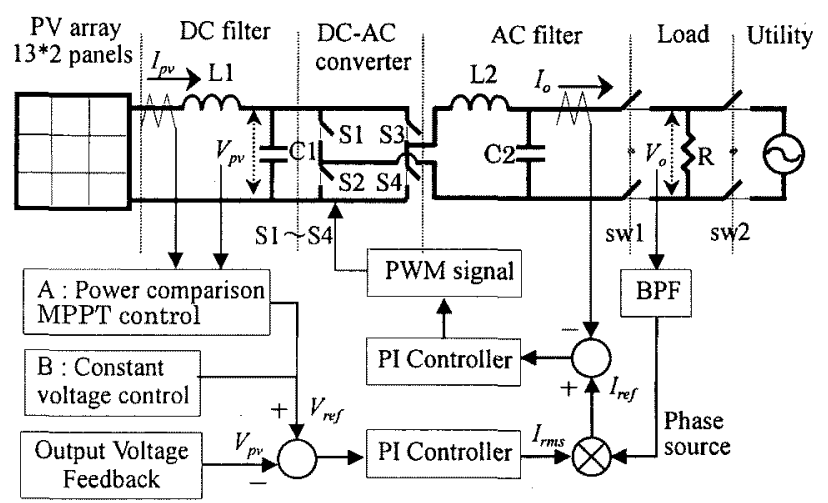

図 13 太陽光発電系統連系システムの概念図

Fig. 13 Diagram of the PV power system with grid connection

表 4 シミュレーション条件および回路パラメータ

Table 4 Simulation condition and circuit parameters

\begin{tabular}{|c|c|c|c|c|c|}
\hline \multirow{2}{*}{$\begin{array}{c}\text { PV } \\
\text { Array } \\
\end{array}$} & \multirow{2}{*}{\multicolumn{3}{|c|}{$\begin{array}{c}13 \text { panels in series } \times 2 \text { in parallel } \\
\left(\mathrm{N}_{\mathrm{s}}=468, \mathrm{~N}_{\mathrm{sl}}=2, \text { Rated power }=900 \mathrm{~W}\right)\end{array}$}} & $V_{\text {oc-arrav }}$ & 250 Volt \\
\hline & & & & $I_{\text {sc-aray }}$ & $6 \mathrm{~A}$ \\
\hline \multirow{2}{*}{$\begin{array}{l}\text { Simulation } \\
\text { Parameters }\end{array}$} & \multicolumn{2}{|c|}{ Simulation time period $5 \mathrm{sec}$} & \multirow{2}{*}{\multicolumn{2}{|c|}{$\begin{array}{c}\text { Calculation } \\
\text { sampling time }\end{array}$}} & \multirow{2}{*}{$1 \mu \mathrm{sec}$} \\
\hline & Data input cycle & $100 \mathrm{~Hz}$ & & & \\
\hline \multirow{4}{*}{$\begin{array}{c}\text { DC-AC } \\
\text { Converter } \\
\text { and } \\
\text { MPPT } \\
\end{array}$} & \multicolumn{2}{|c|}{ PWM switching frequency } & \multicolumn{3}{|c|}{$10 \mathrm{kHz}$} \\
\hline & \multirow{2}{*}{\multicolumn{2}{|c|}{$\begin{array}{l}\text { Power comparison MPPT control } \\
\text { (Control cycle 20Hz) }\end{array}$}} & & A-1 & $\mathrm{V}=2$ Volt \\
\hline & & & & -2 & $V=5$ Volt \\
\hline & \multicolumn{2}{|c|}{ Constant voltage control } & & B & 200 Volt \\
\hline \multirow{2}{*}{$\begin{array}{l}\mathrm{DC} \text { and } \mathrm{AC} \\
\text { Filter } \\
\end{array}$} & $\mathrm{Cl}$ & $8000 \mu \mathrm{F}$ & $\mathrm{L}$ & & $1 \mathrm{mH}$ \\
\hline & $\mathrm{C} 2$ & $2 \mu \mathrm{F}$ & $\mathrm{L} 2$ & & $7 \mathrm{mH}$ \\
\hline \multirow{2}{*}{$\begin{array}{l}\text { Utility } \\
\text { network }\end{array}$} & \multicolumn{3}{|c|}{ Voltage of utility power network } & \multicolumn{2}{|c|}{$\mathrm{AC} 100$ Volt } \\
\hline & \multicolumn{3}{|c|}{ Frequency of utility power network } & \multicolumn{2}{|c|}{$60 \mathrm{~Hz}$} \\
\hline
\end{tabular}


表 4 は、シミュレーション条件及び回路定数である。ま た、天候条件は図 14 に示す。

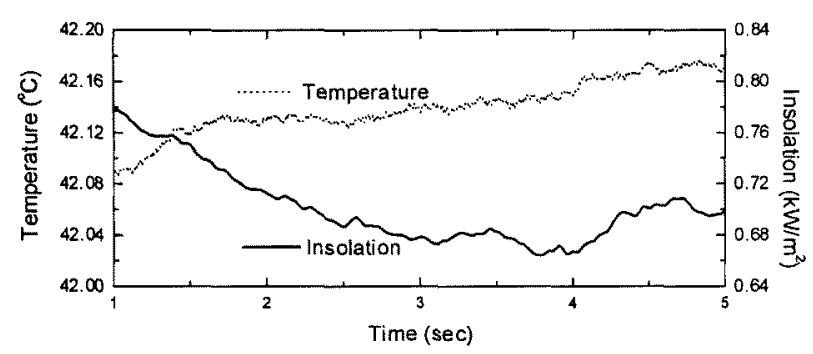

図14 シミュレーション上で用いた実天候条件

Fig. 14 Real field weather condition used in the simulation

<5.2> シミュレーション解析結果 今回、最大電力追 従制御としては、制御系が簡単で安定性が高いとされる一 定電圧方式と最も一般化された山登り方式(13-14)の 2 方式を取 り上げ、それぞれについて解析を行った。表 4 に示すよう に、山登り方式は制御周期 $20 \mathrm{~Hz}$ で電圧変化量を 2 [Volt]、 5[Volt]とした時、一定電圧方式は 200[Volt]一定とした時の 解析を行った。図 15 、図 16 に太陽電池アレイの出力電 力と電圧電力 $(\mathrm{PV})$ 特性を示し、図 17 にインバータの出力 電流波形を示寸。

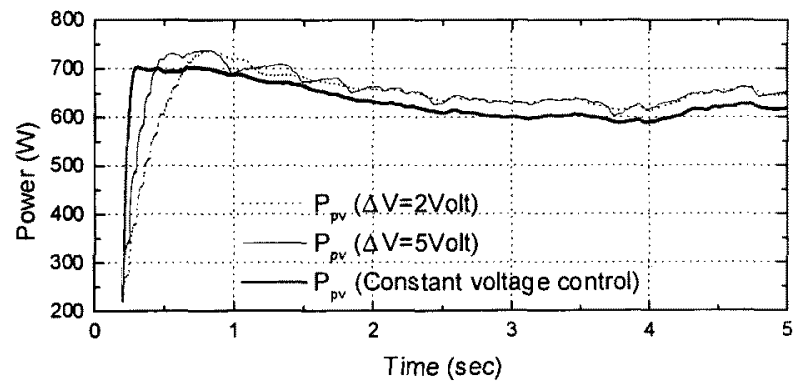

図 15 MPPT 制御による太陽電池アレイの出力電力推移

Fig. 15 Output power curves of PV array by MPPT controls

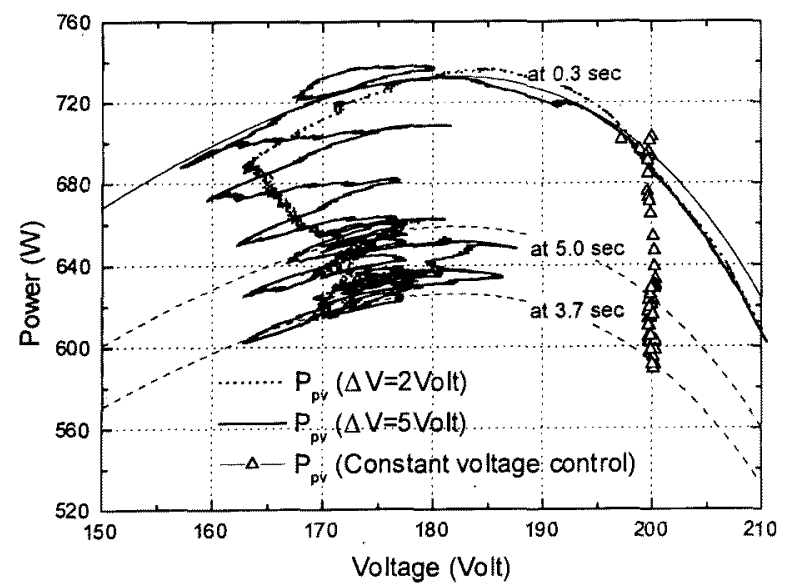

図 16 MPPT 制御による太陽電池アレイの電圧電力特性

Fig. 16 Voltage-power characteristics of PV array by MPPT controls

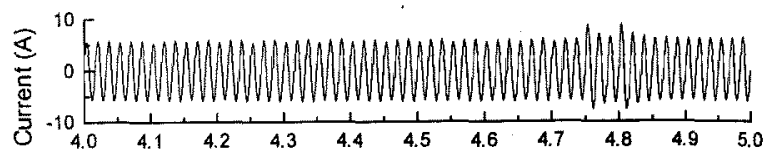

(a) $\Delta V=2$ Volt

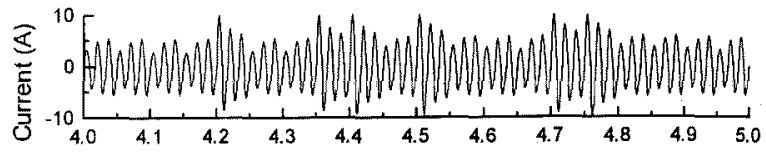

(b) $\Delta V=5$ Volt

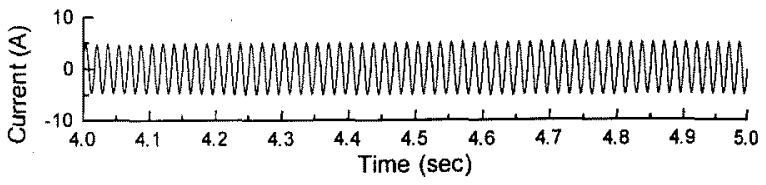

(c) Constant voltage control

図 17 MPPT 制御によるインバータ出力電流特性

Fig. 17 Output current characteristics of converter by MPPT controls

図15から、一定制御方式よりも山登り方式の方が、高 い電力を得られることが確認できる。図 16 の PV 特性から、 一定電圧方式は出力電圧の変動が少なく安定した動作をす るが、山登り方式は、常に最大電力点に追従しようとする ため出力電圧の変動が大きく現われることが確認できる。

これらの電圧変動の影響により、図 17 に示すようにイン バータの出力電流にも变動が生じている。以上の結果より $2 つ$ 制御方式の特徵を簡単にまとめると、山登り方式は、 常に最大電力点を追従するため高い電力量が得られるが、 電圧変化量の選択などによって出力の電圧、電流変動が大 きく現われる。これは、接続される系統から見れば安定し て供給している電力に不安定要素が重盢されたことと等し くなるため、系統に対する影響を懸念しなければならない。 一方、一定電圧方式は電圧、電流変動がほとんど現われな いため、系統に対する影響を䀣念する必要はない。しかし、 最大電力点加らは外れた動作電圧となるため、高い電力量

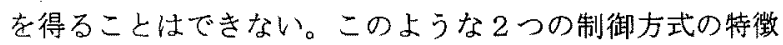
やデメリットは、これまでに行われてきた椂々な研究者に よる報告の中で広く認知されてきていた内容と一致してお り(15)、系統や制御も含んだシステムに対しても提案したシ ミュレーションカ法により得られる解析結果の妥当性は確 認されたといえる。最後に、この解析は同じ天候条件を用 いて行っている。今までは、複数の同一規格の装置を準備 した実験でなくてはできなかった同じ天候条件下での解析 結果は得られなかったが、シミュレーションでそれを実現 できたことが大きな成果の1つである。

6. むすび

本論文では、実際の天候条件を用いた太陽光発電システ ムの新しいシミュレーション方法を提案し、実験結果との 比較検討を行った。得られた結果は以下に示す通りである。

(1)シミュレーションツールとして電カシステム研究者た ちの間に最も一般化されている EMTP 型シミュレータを用 い、ツール上で新しい太陽電池の詳細なモデルを示した。 
(2) フォートラン言語とのインターフェース法を導入する ことにより、ノンリニアな外部パラメータである日射強度 や表面温度をデータとしてツールに読み込み、実天候条件 を考慮したシミュレーション解析が行えるようになった。

(3) 実際に設置した太陽電池アレイの出力電流、電圧の測 定結果とシミュレーション結果とを比較したところ、よく 一致することが確認され太陽電池の詳細なモデル化の妥当 性を示すことができた。

(4) 電力変換装置、最大電力追従制御、系統連系を含んだ 太陽光発電システムの特性解析を行った結果、実験結果上 もよく一致し、制御系の違いによる動作の特徽も捉えるこ とが可能であることが確認された。

以上の結果より、実天候条件を用いた新しいシミュレー ション方法の有効性および妥当性が確認された。提案した シミュレーション方法を利用すれば、太陽電池の種類や規 模、電力変換装置、最大電力追従制御など様々な条件下で の解析が容易に安価で行えることになる。そして、実際の 天候条件を用いることでより現実に近いシミュレーション 解析が行えることになったことが大きな成果の 1 つである と思われる。今後、シミュレーション解析も含め太陽光発 電に関する研究開発が益々盛しに行われることを期待する。

(平成 13 年 2 月 9 日受付、平成 13 年 5 月 18 日再受付)

文 献

[1] Francois Giraud, Zyiad M. Salameh, "Steady-State Performance of a Grid-Connected Rooftop Hybrid Wind-Photovoltaic Power System with Battery Storage", IEEE Transactions on Energy Conversion, Vol. 16, No. 1, pp.1-7, March 2001

[2]Bogdan S. Borowy, Ziyad M. Salameh, "Methodology for Optimally Sizing the Combination of a Battery Bank and PV Array in a Wind/PV Hybrid System", IEEE Transactions on Energy Conversion, Vol. 11, No. 2, pp.367-373, June 1996

[3]M. Muselli, G. Notton, P. Poggi, A. Louche, "PV-hybrid power systems sizing incorporrating battery storage: an analysis via simulation calculations", Renewable Energy 20 (2000) 1-7

[4]朴敏遠、松浦虔士、道平雅一、「実データを用いた太陽電池の新し いシミュレーション方法小、電気学会 B 部門論文誌、121 巻 2 号、 平成 13 年、pp262-263

[5]山下博史、道平雅一、津吉彰、朴敏遠、舟木剛、松浦虔士、「太陽 光発電の実データ用いたシミュレーション解析法小平成 13 年半導 体電力変換研究会 SPC-01-14、2001

[6]「パワーエレクトロニクスシステムのシミュレーション技術」、 電気学会技術報告、第 761 号、平成 13 年

[7] [EMTP Rule Book] Bonneville Power Administration, Route EOGB, P.O. Box 3621, Portland, Oregon, USA.

[8] [PSCAD/EMTDC Power System Simulation Software Manual] Monitoba HVDC Research Centre

[9] Martin A. Green "Solar Cells Operating Principles, Technology, and System Applications", 1982 by Prentice-Hall, Inc., Englewood Clifts, N.J. 07632

[10]伊賀淳、「太陽電池の光照射状態の電圧一電流特性式を用いた I-V カーブ作成法とその活用、、電気学会 D 部門論文誌、116 巻 10 号、 平成 8 年、pp1001-1009

[11]「全天日射計 MS - 601、601F 取扱説明書」EKO 精機株式会社

[12] 丁路、牧野康宏、「太陽電池の一定電圧制御に関する検討」平成 5 年電気学会全国大会 $\mathrm{p} 5-161-5-162 、 1993$

[13] T. Kawamura et al. "Analysis of MPPT Characteristics in Photovoltaic Power System", Journal, Solar Energy Materials and Solar Cells Vol.47 pp.155-165, 1997

[14] Tsai-Fu Wu, Chien-Hsuan Chang, Yu-Kai Chen, "A Fuzzy-LogicControlled Single-Stage Converter for PV-Powered Lighting System Applications", T. IEEE on Industrial Electronics, Vol. 47, No. 2, pp287296, April 2000

[15] 小玉博一、「太陽光発電システムと系統連倸（II）」第 10 回専門 講習会デキスト、分散型電力変換システムの基礎と忘用、1995

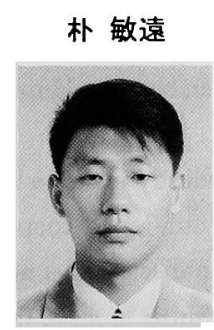

(学生員) 昭和 45 年 2 月 12 日生。平成 7 年 2 月韓国国立昌原大学校工科大学電気 工学科卒業。平成 9 年 2 月、同大学修士 課程修了。平成 10 年 4 月大阪大学大学院 工科研究科博士前期課程入学、平成 12 年 4 月同大学博士後期課程入学、現在に至 る。主に、パワーエレクトロニクス制御、 分散電源システムに関する研究に従事。

昖浦 虔士 (終身会員) 昭和 13 年 1 月 1 日生。昭和 37

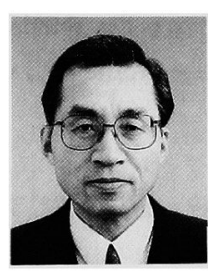
年 3 月大阪大学大学院工科研究科博士前 期修了。同年 4 月住友電気工業（株）入 社。昭和 52 年 1 月大阪大学工学部電気工 学科助教授。昭和 63 年 3 月同教授。工学 博士。主に、電気エネルギーの発生・伝 送・変換・制御に関する研究に従事。電 気学会終身会員。

山下 博史 (学生員) 昭和 54 年 9 月 12 日生。平成 12

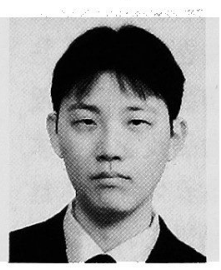
年 3 月神戸市立工業高等専門学校電気工 学科卒業。同年 4 月神戸市立工業高等専 門学校専攻科電気電子工学専攻入学、現 在に至る。主に太陽光発電、パワーェレ クトロニクス回路方式に関する研究に従 事。電気学会学生員。

道平 雅一

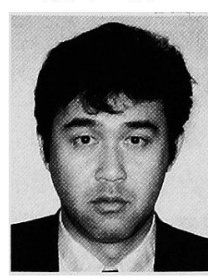

（正員）昭和 44 年 12 月 3 日生。平成 7 年 3 月神戸大学大学院工学研究科修士課程 修了。平成 10 年 3 月大阪大学大学院工学 研究科博士後期課程修了、同年 4 月神戸 市立工業高等専門学校電気工学科助手、 平成 11 年 4 月同講師、現在に至る。工学 博士。主に、パワーエレクトロニクス回 路方式及び制御に関する研究に従事。 